\title{
REDESCRIPTION OF THE CAVE-DWELLING BRACHYDESMUS TROGLOBIUS DADAY, 1889 (DIPLOPODA, POLYDESMIDA)
}

\author{
Dorottya Angyal ${ }^{1,2}$, Slobodan E. Makarov ${ }^{3}$ and Zoltán Korsós ${ }^{1}$ \\ ${ }^{1}$ Department of Zoology, Hungarian Natural History Museum, H-1088 Budapest, Baross u. 13, \\ Hungary; E-mails: angyal.dorottya@nhmus.hu, korsos@nhmus.hu \\ ${ }^{2}$ Laboratory of Molecular Taxonomy, Hungarian Natural History Museum, H-1083 Budapest, \\ Ludovika tér 2-6, Hungary \\ ${ }^{3}$ Institute of Zoology, Faculty of Biology, University of Belgrade, 11000 Studentski trg 16, \\ Belgrade, Serbia; E-mail: slobodan@bio.bg.ac.rs
}

The cavernicolous polydesmid Brachydesmus troglobius Daday, 1889 was described from the Hungarian Abaligeti Cave (Mecsek Mountains). Although previously known from only its type locality, the species was later found in caves of other European countries. Redescription of the species from museum samples and newly collected material using optical and scanning electron microscopy is here complemented with mitochondrial cytochrome c oxidase subunit I (COI) sequences as barcodes. New distributional data, remarks on the species' ecology and suggestions for its conservation are also given. Using COI sequences of 17 polydesmid taxa from GenBank and our own collections, we delimit interspecific and intergeneric boundaries within the family Polydesmidae.

Key words: Hungary, Western Mecsek Mountains, caves, polydesmid, redescription, phylogeny, troglobiont.

\section{INTRODUCTION}

The polydesmid millipede Brachydesmus troglobius Daday, 1889 was first found in the Abaligeti Cave (South Hungary, Mecsek Mountains) on an unknown date by the Hungarian entomologist János Pável (1842-1901). It was described as a species endemic to the cave (DADAY 1889) by Jenô Daday (1855-1920), curator of invertebrates in the Hungarian National Museum. The rather short description, written in Latin, did not contain any drawings; however, Daday commented on the similarity to B. subterraneus Heller, 1858: the two quite similar species can be distinguished by the different shape and structure of the collum and the gonopods. Verhoeff (1928) described and illustrated the gonopods of $B$. troglobius in a publication on the Hungarian millipede fauna. Later faunistic records from the Abaligeti Cave were published by Boкor (1924), Gebhardt $(1934,1963,1967)$, Korsós (2000), Korsós et al. 
(2006) and Angyal and Korsós (2013). B. troglobius was collected in numerous caves in the Dinaric Karst, as well, and there are records from Croatia, Montenegro, Romania, Serbia and Slovenia (Strasser 1971, Mršić 1988, 1994, 1998, Ćurčić \& Makarov 1998, Makarov 2004, Enghoff 2013). Ceuca (1992) published a paper about the variability of the gonopod in Romanian populations of some Polydesmus and Brachydesmus - including B. troglobius - species. ĆUrČıć and MaKarov (1998) described the postembryonic development of $B$. troglobius in samples from Lazareva Cave (Serbia), and revealed that the species completes its entire life cycle within the cave. However, Gebнardt (1966) and Mršrć (1988) mention the observation of epigean populations in Hungary and Serbia. MaKarov et al. (2012) studied the chemical defense of the species and showed that it secretes allomones against predators.

'Integrative taxonomy' is the science that aims to delimit the units of life's diversity from multiple and complementary perspectives, applying comparative morphology, phylogeny, population genetics, ecology, development, behaviour, etc. (DAYRAT 2005). For phylogenetic reconstruction in the order Polydesmida, cladistic analysis based solely on morphological characters has been the traditional method (e.g. Simonsen 1990, Bueno-Villegas et al. 2008, Djursvoll et al. 2000). However, recently, application of molecular taxonomic data for the same purpose also started to unfold (e.g. MAREK \& Bond 2006, MareK \& Bond 2007, SPelda et al. 2011).

The isolated Mecsek Mountains are situated in South Hungary and surrounded by the Pannonian plains (Fig. 1). The range is populated by a relatively high number of locally endemic species, the origin of which may date back to the Tertiary and therefore may have survived mass extinctions in previous glacial periods (GевнаRDt 1967). The subterranean environment of the Mecsek Mts harbors numerous endemic terrestrial and aquatic invertebrates, known only from one or a few caves (AngYal et al. 2015). Using preserved museum samples and newly collected material from two caves of the Mecsek Mts (including the type locality), our aim was to contribute to the knowledge of the morphology and molecular genetics of B. troglobius with the help of scanning electron microscopy, DNA barcoding and phylogenetic analysis. Our additional aim was to improve understanding of the species' distribution and ecology and to provide a basis for future conservation management decisions. 
Table 1. Basic data of the Abaligeti Cave and the Törökpince Cave (both in Mecsek Mts).

\begin{tabular}{lcc}
\hline Name of cave & Abaligeti Cave & Törökpince Cave \\
\hline Type of cave & outflow cave & inflow cave \\
Cadastre number & $4120-1$ & $4120-13$ \\
Entrance's altitude above sea level (m) & 218 & 275 \\
Entrance's coordinates (WGS-84 FI) & $46^{\circ} 08^{\prime} 11^{\prime \prime} \mathrm{N}$ & $46^{\circ} 07^{\prime} 57^{\prime \prime} \mathrm{N}$ \\
Entrance's coordinates (WGS-84 LA) & $18^{\circ} 06^{\prime} 59^{\prime \prime} \mathrm{E}$ & $18^{\circ} 06^{\prime} 35^{\prime \prime} \mathrm{E}$ \\
Length of cave (m) & 2000 & 87 \\
Vertical extension of cave (m) & 48 & 7 \\
\hline
\end{tabular}

\section{MATERIAL AND METHODS}

\section{Sampling sites and methods}

Fourteen caves of Western Mecsek Mts (South Hungary) were regularly visited between 2010 and 2013 to sample their fauna. Among these, B. troglobius populations were

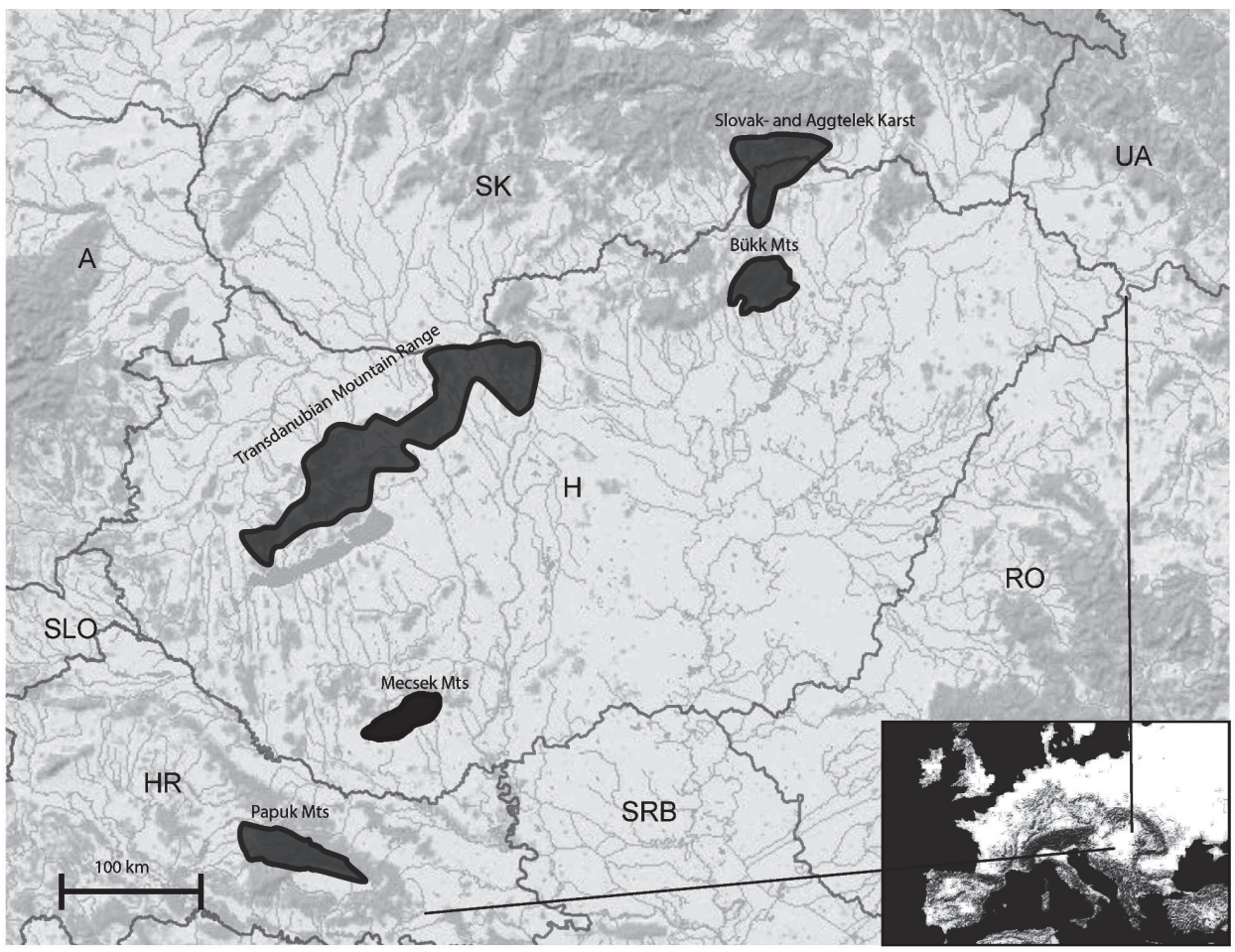

Fig. 1. Location of the Mecsek Mts among the Hungarian karstic mountains and the Croatian Papuk Mts (map by G. Balázs) 
found only in the type locality (Abaligeti Cave) and the Törökpince Cave. Both of these are situated near Abaliget village (18 km from Pécs city), and their entrances open less then a kilometre from each other. Basic data of the two caves are listed in Table 1. The highly protected Abaligeti Cave is the largest cave known in the Mecsek Mts. With its three collaterals (Eastern, Western 1 and Western 2) and the main passage, the total length of the cave is $2000 \mathrm{~m}$. Its lowest point below the entrance is $10 \mathrm{~m}$, while its highest point is $38 \mathrm{~m}$ above the entrance (Havasi et al. 2003). The Western 2 collateral is in connection with the Akácos Cave, which serves as a second entrance to the Abaligeti Cave. The Abaligeti Cave is characterized by both streaming and stagnant water. The most significant nutrient source of the cave is vegetable material of epigean origin aggregated in the stream's alluvium and the decaying wooden fragments introduced by human activity. The cave has been opened to the public since 1957. Some of the most attractive speleothem formations are illuminated by lamps, which has caused the development of a 'lamp flora' serving as an alternative energy source for the cave-dwelling invertebrates (ANGYAL 2015). Bat guano accumulations are not a substantial element of the ecosystem, as the formerly vast bat colonies have been recently reduced (SZATYOR 2005). At $12.6{ }^{\circ} \mathrm{C}$, the average temperature of the cave is relatively high, and considerable fluctuation can be detected only up to $40-50 \mathrm{~m}$ from the entrance. The relative air humidity is $97 \%$.

The Törökpince Cave is formed in conglomerate. The cave opens with an extremely tight entrance aperture, which continues in an $87 \mathrm{~m}$ long, narrow horizontal passage. Recently, the cave has proven to be dry in all seasons. As the cave directly opens in deciduous woodland, its first few meters contain a massive amount of organic matter, which supports the existence of trogloxene invertebrate species in the entrance zone.

In both caves, specimens were collected by hand using entomological (soft) forceps or an aspirator, and by baited or unbaited pitfall traps. Among the different types of baits (meat, dog food, cheese, beer) used for sampling the cave invertebrate fauna, only the beer attracted the millipedes. Specimens were preserved and stored in $70 \%$ ethanol for morphological purposes and in 96\% ethanol for molecular studies, and are deposited in the Myriapoda Collection of the Hungarian Natural History Museum (HNHM), Budapest.

\section{Morphological studies}

Brachydesmus specimens were examined under a Leica M125 stereomicroscope. In some cases the male's gonopods were dissected and studied under higher magnification. A drawing tube mounted on a Leica DM1000 light microscope was used for making drawings. Redescription was made using the characters of Polydesmida character matrix by DJuRsvoll et al. (2000) and the characters of ANTic et al. (2013), which follow modern trends in millipede morphological taxonomy. Scanning electron micrographs of the main characters of a male and a female specimen of B. troglobius were made with a Hitachi S-2600 N scanning electron microscope in the Department of Botany of the HNHM. Specimens were placed in absolute ethanol for one day, then cleaned in an EMAG Emmi-16 Ultrasonic Cleaner and air-dried. Dry samples were attached to stubs and were sputter-coated by gold-palladium. Micrographs were digitally edited. Multilayer photos of entire specimens were taken in the Department of Zoology of the HNHM with a Nikon D5200 camera using Mitutoyo M Plan Apo 5X microscope lens and single flash diffused with a paper cylinder. Exposures were stacked with Zerene Stacker software. 
Table 2. New COI samples used in the phylogenetic analysis. Abbreviations: HU = Hungary, RS = Republic of Serbia; DA = Dorottya Angyal, SM = Slobodan Makarov.

\begin{tabular}{|c|c|c|c|c|c|c|}
\hline $\begin{array}{l}\text { Genbank acces- } \\
\text { sion number }\end{array}$ & Species & $\begin{array}{l}\text { Coun- } \\
\text { try }\end{array}$ & $\begin{array}{l}\text { Region, } \\
\text { town }\end{array}$ & Cave name & $\begin{array}{l}\text { Date } \\
\text { of col- } \\
\text { lection }\end{array}$ & $\begin{array}{l}\text { Col- } \\
\text { lec- } \\
\text { tor }\end{array}$ \\
\hline $\begin{array}{l}\text { KT343290 } \\
\text { (BR_TRO/Aba) }\end{array}$ & $\begin{array}{l}\text { B. troglobius } \\
\text { Daday, } 1889\end{array}$ & $\mathrm{HU}$ & $\begin{array}{l}\text { Mecsek, } \\
\text { Abaliget }\end{array}$ & Abaligeti & $\begin{array}{c}13.06 . \\
2013\end{array}$ & $\mathrm{DA}$ \\
\hline $\begin{array}{l}\text { KT343289 } \\
\text { (BR_TRO/Ser) }\end{array}$ & $\begin{array}{l}\text { B. troglobius } \\
\text { Daday, } 1889\end{array}$ & RS & $\begin{array}{c}\text { West Serbia, } \\
\text { Valjevo }\end{array}$ & Petnička & $\begin{array}{c}21.05 . \\
2010\end{array}$ & SM \\
\hline $\begin{array}{l}\text { KT343291 } \\
\text { (BR_SUP/Alba) }\end{array}$ & $\begin{array}{c}\text { B. superus } \\
\text { Latzel, } 1884\end{array}$ & $\mathrm{HU}$ & $\begin{array}{c}\text { Bakony, } \\
\text { Csőszpuszta }\end{array}$ & Alba Regia & $\begin{array}{c}10.11 . \\
2012\end{array}$ & DA \\
\hline $\begin{array}{l}\text { KT343292 } \\
\text { (BR_HER/Ser) }\end{array}$ & $\begin{array}{l}\text { B. herzogowinensis } \\
\text { Verhoeff, } 1897\end{array}$ & RS & $\begin{array}{l}\text { West Serbia, } \\
\text { Ivanjica }\end{array}$ & $\begin{array}{l}\text { Hadži } \\
\text { Prodanova }\end{array}$ & $\begin{array}{c}23.07 . \\
2012\end{array}$ & SM \\
\hline $\begin{array}{l}\text { KT343288 } \\
\text { (PO_DEN/Soly) }\end{array}$ & $\begin{array}{l}\text { P. denticulatus } \\
\text { C. L. Koch, } 1847\end{array}$ & $\mathrm{HU}$ & $\begin{array}{l}\text { Budai Mts, } \\
\text { Solymár }\end{array}$ & $\begin{array}{l}\text { Solymári- } \\
\text { ördöglyuk }\end{array}$ & $\begin{array}{c}03.03 . \\
2012\end{array}$ & DA \\
\hline
\end{tabular}

\section{Molecular studies}

DNA extraction of three Brachydesmus and one Polydesmus species from five different caves in Hungary and Serbia was performed in the Laboratory of Molecular Taxonomy of the HNHM, using QIAamp DNA Microkit® (QIAGEN) following the manufacturer's instructions. Data for the samples used are listed in Table 2. The primer pairs were used for PCR amplifications of cytochrome c oxidase subunit I (COI) were LCO 1490 - HCO 2198 (Folmer et al. 1994) and LCO 1490 - COI-H (МАсноDrom et al. 2003) (Table 3). PCR products were cleaned using Roche High Pure Purification Kit ${ }^{\circledR}$ according to manufacturer's instructions. Fragments were sequenced in an ABI 3130 sequencer, using PCR amplification primers.

Protocols and thermo profiles used in PCR were as follows:

Primers: LCO 1490 (forward), HCO 2198 (reverse)

PCR reactions (ca $25 \mu \mathrm{l}$ total) were obtained by mixing $10.775 \mu \mathrm{lmQ}$ water, $2.5 \mu \mathrm{l} 10 \times$ PCR buffer (with $\mathrm{MgCl}_{2}$ ), $3.125 \mu \mathrm{l} \mathrm{dNTP}, 1.75 \mu \mathrm{l}$ of each primer $(5 \mu \mathrm{M}), 0.01 \mu \mathrm{l}$ Fermentas Dream Taq DNA Polymerase ${ }^{\circledR}(5 \mathrm{U} / \mu \mathrm{l})$ and $5 \mu \mathrm{l}$ DNA extract. PCR cycling: initial denaturation for $1 \mathrm{~min}$ at $95^{\circ} \mathrm{C}$, denaturation for $1 \mathrm{~min}$ at $94{ }^{\circ} \mathrm{C}$, hybridization for $1 \mathrm{~min} 30 \mathrm{sec}$ at $42.9^{\circ} \mathrm{C}$, and polymerization for $1 \mathrm{~min} 30 \mathrm{sec}$ at $72{ }^{\circ} \mathrm{C}$. After 40 cycles the sample was left for $6 \min 72^{\circ} \mathrm{C}$.

Table 3. Primers used with Brachydesmus and Polydesmus species.

\begin{tabular}{ccccl}
\hline Marker & Primer & Direction & Sequence & Reference \\
\hline COI & LCO 1490 & Forward & 5' GGTCAACAAATCAT- & Folmer et al. 1994 \\
& & & AAAGATATTGG 3' & \\
COI & HCO 2198 & Reverse & 5' TAAACTTCAGGGT- & Folmer et al. 1994 \\
& & & GACCAAAAAAT 3' & \\
COI & COI-H & Reverse & 5' TCAGGGTGAC- & MACHOdrom et al. 2003 \\
& & & CAAAAAATCA 3' & \\
\hline
\end{tabular}




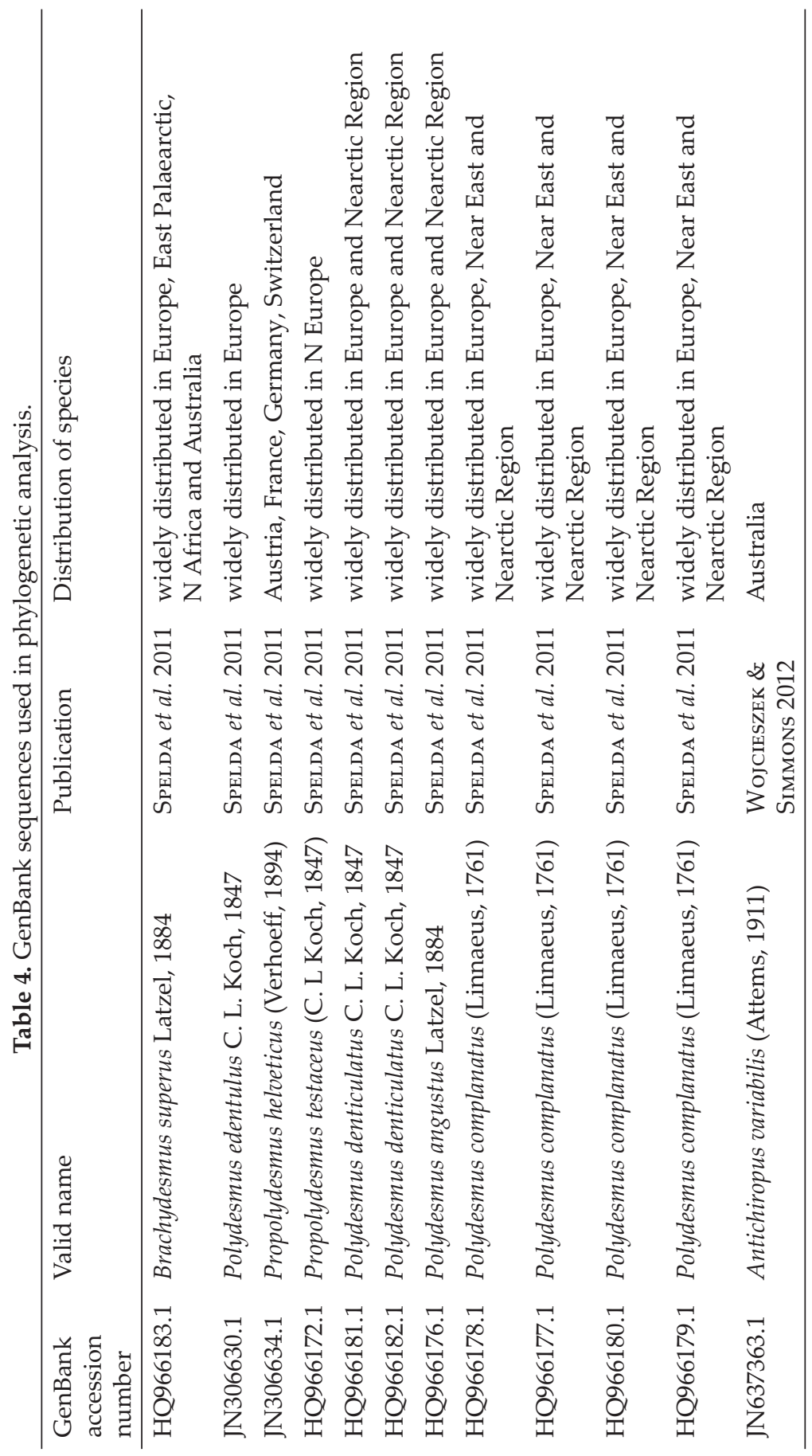


Primers: LCO 1490 (forward), COI-H (reverse)

PCR reactions (ca $25 \mu \mathrm{l}$ total) were obtained by mixing $8.775 \mu \mathrm{lmQ}$ water, $2.5 \mu \mathrm{l} 10 \times$ PCR buffer, $2 \mu \mathrm{l} 25 \mathrm{mM} \mathrm{MgCl}_{2}, 3.125 \mu \mathrm{l}$ dNTP mix $(2 \mathrm{mM}), 1.75 \mu \mathrm{l}$ of each primer $(5 \mu \mathrm{M})$, $0.1 \mu \mathrm{l}$ Fermentas Taq Polymerase ${ }^{\circledR}(5 \mathrm{U} / \mu \mathrm{l})$ and $5 \mu \mathrm{l}$ DNA extract. PCR cycling: initial denaturation for $1 \mathrm{~min}$ at $94{ }^{\circ} \mathrm{C}$, denaturation for $1 \mathrm{~min}$ at $94{ }^{\circ} \mathrm{C}$, hybridization for $1 \mathrm{~min} 30$ sec at $40{ }^{\circ} \mathrm{C}$, and polymerization for $1 \mathrm{~min} 30 \mathrm{sec}$ at $72{ }^{\circ} \mathrm{C}$. After 40 cycles the sample was left for 6 min at $72{ }^{\circ} \mathrm{C}$.

\section{Phylogenetic analysis}

In order to evaluate the phylogenetic relationships within the genus Brachydesmus Heller, 1858, as well as the intergeneric distances between Brachydesmus and other polydesmid genera, a dataset of COI markers was complied, using our own data and sequences downloaded from GenBank. Accession numbers for our own samples are listed in Table 2. Another five polydesmid species were included in the dataset (Table 4), summing up a total of nine polydesmid species in three genera. For Brachydesmus, only B. superus sequence was available from GenBank at the time of our analysis. Antichiropus variabilis (Paradoxosomatidae) was included in the dataset as outgroup taxon.

The DNA sequences were aligned with ClustalW (Thompson et al. 1994) implemented in MEGA 6.06 (TAmura et al. 2013). Nucleotide substitution model selection carried out with MEGA V6.0 using the Bayesian information criterion (BIC) (SchwARz 1978) revealed that the best fitting model for COI is GTR $+\mathrm{G}+\mathrm{I}$. Phylogenetic tree was constructed using Bayesian analysis with BEAST 1.8.0 (Drummond \& RAmbaut 2007) using Metropolis coupled Markov chain Monte Carlo simulations for 10 million generations, sampling a tree in every 1000 generations. After removing the first 2000 trees as burn-in, the remaining 8000 sampled trees were analyzed with TreeAnnotator v1.8.0 and visualized by FigTree 1.4.0 (Rambaut 2012). Pairwise genetic distances were calculated in MEGA 6.06 using the Kimura 2-Parameter model (KIMURA 1980).

\section{RESULTS}

\section{Redescription of Brachydesmus troglobius Daday, 1889}

(Figs 2-7)

Brachydesmus troglobius: Daday 1889 (description), Verhoeff 1928 (additional morphological data), Boкоr 1924 (faunistic data), GeвнARdт 1934, 1963, 1967 (faunsitic data), STRAsSer 1971 (distributional data), Mršić 1988 (distributional data), Mršıć 1994, 1998 (distributional data), Ceuca 1992 (morphological data), Ćurčić \& Makarov 1998 (morphological data), Korsós 2000 (faunistic data), MaKarov et al. 2004, (distributional data), Korsós et al. 2006 (faunistic data), Makarov et al. 2012 (physiological data), Angyal \& Korsós 2013 (additional distributional data), ENGHOFF 2013 (distributional data).

Material examined - Historic museum samples: 830/1888, 205/253, Abaligeti Cave, leg. ?, det. J. Daday, revid. D. Angyal, 2015: 2 , , broken, in bad condition, labeled as SYNTYPES; 1722/1928, Abaligeti Cave, 21/10/1922, leg. E. Bokor, det. K. W. Verhoeff, revid. E. Loksa, 245/1953, revid. D. Angyal, 2015: 5 ㅇ, 3 đ̊; 1720/1928, Abaligeti Cave, 10/1923, leg. E. Bokor, det. K. W. Verhoeff, revid. E. Loksa, 240/1953, revid. D. Angyal, 2015: 2 क; 1721/1928, 
Abaligeti Cave, 12/08/1924, leg. E. Dudich, det. K. W. Verhoeff, revid. E. Loksa, 234/1953, revid. D. Angyal, 2015: 2 ㅇ, 1 O , 2 juv.; 1719/1928, Abaligeti Cave, 15/03/1925, leg. E. Bokor, det. K. W. Verhoeff, revid. Loksa 257/1953, revid. D. Angyal, 2015: 1 o, 1 ; ; 40, Abaligeti Cave, 19/05/1930, leg.?, det.?, revid. D. Angyal, 2015: 25 q, 4 ô, 11 juv.; 3571, Abaligeti Cave, 12/09/1991, leg. Z. Korsós \& H. Read, det. Z. Korsós, revid. D. Angyal, 2015: 2 , 1 juv.

Newly collected material: BRT-01, Abaligeti Cave, Western 2 collateral, 25/11/2010, leg. D. Angyal, det. Z. Korsós, 1 đ̊; BRT-02, Abaligeti Cave, main passage, 22./09/2010, leg. D. Angyal, det. Z. Korsós, 1 ¿ ; BRT-03, Abaligeti Cave, entrance of Western 2 collateral, 09/12/ 2010, leg. D. Angyal, det. D. Angyal, 2 đ̂; BRT-04, Abaligeti Cave, main passage, 350 $\mathrm{m}$ from entrance, on lamp flora, 04/11/2010, leg. D. Angyal, det. Z. Korsós, 1 ; BRT-05, Abaligeti Cave, main passage, 'Nagyterem', on lamp flora, 23/11/2010, leg. D. Angyal, det. D. Angyal, 1 , 1 juv; BRT-06, Törökpince Cave, $30 \mathrm{~m}$ from entrance, 27/10/2010, leg. D. Angyal, det. Z. Korsós, 1 +; BRT-07, Abaligeti Cave, Western 2 collateral, 25/11/2010, leg. D. Angyal, det. Z. Korsós, 1 juv.; BRT-08, Abaligeti Cave, main passage, before the siphon, 10/11/2010, leg. D. Angyal, det. Z. Korsós, 1 +; BRT-09, Abaligeti Cave, Eastern collateral, 23/11/2010, leg. D. Angyal, det. D. Angyal, 1 + , 1 d ; BRT-10, Abaligeti Cave, Eastern collateral, 22/09/2010, leg. D. Angyal, det. D. Angyal, 1 juv.; BRT-11, Abaligeti Cave, entrance of Western 2 collateral, 19/04/2011, leg. D. Angyal, det. D. Angyal, 1 juv.; BRT-12, Abaligeti Cave, main passage, $350 \mathrm{~m}$ from entrance, on lamp flora, 22/09/2010, leg. D. Angyal, det. D. Angyal, 1 đ.; BRT-13, Abaligeti Cave, main passage, upper passage before the siphon, 23/03/2013, leg. D. Angyal, A. Mock \& P. Luptačik, det. D. Angyal, 1 đ̊; Abaligeti Cave,

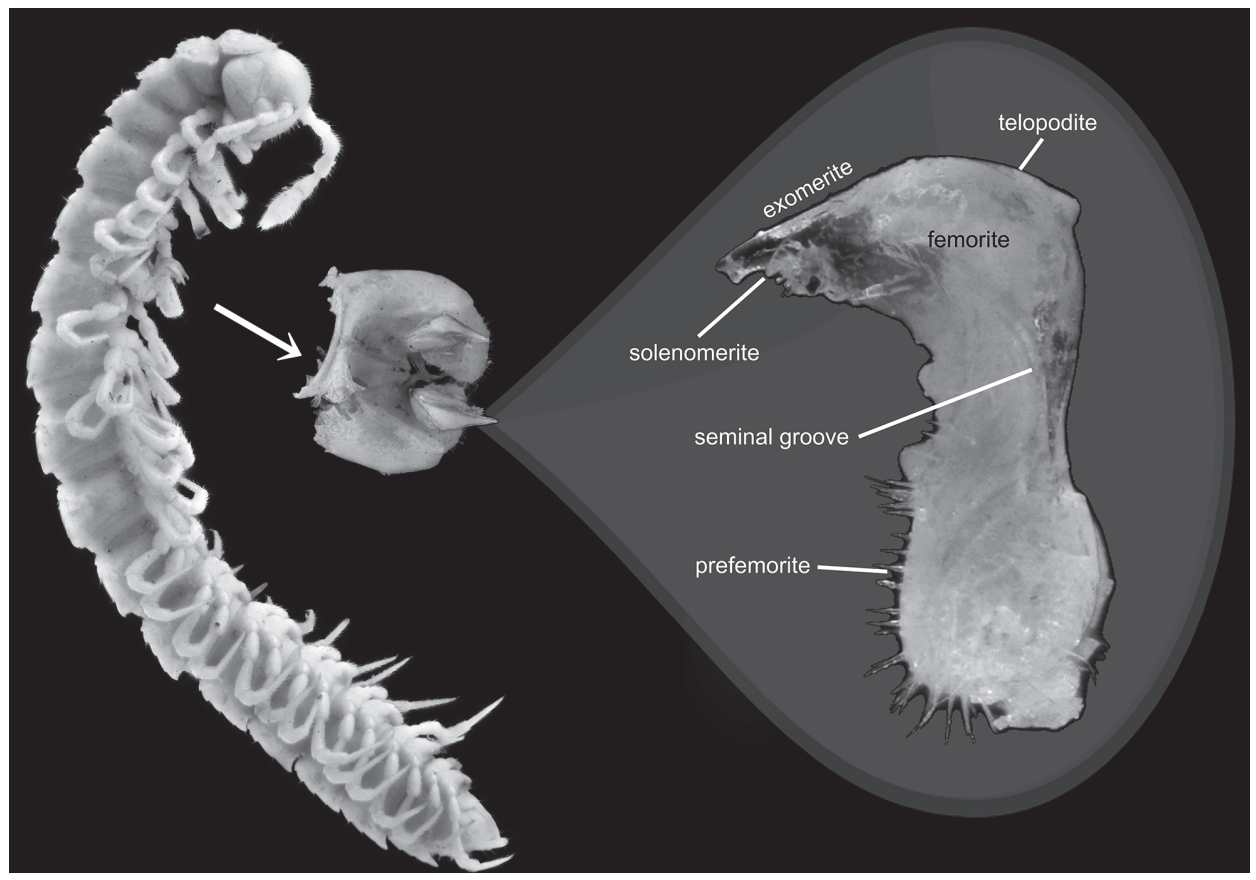

Fig. 2. Brachydesmus troglobius, male from the Abaligeti Cave, habitus and gonopods (photo by T. Németh) 


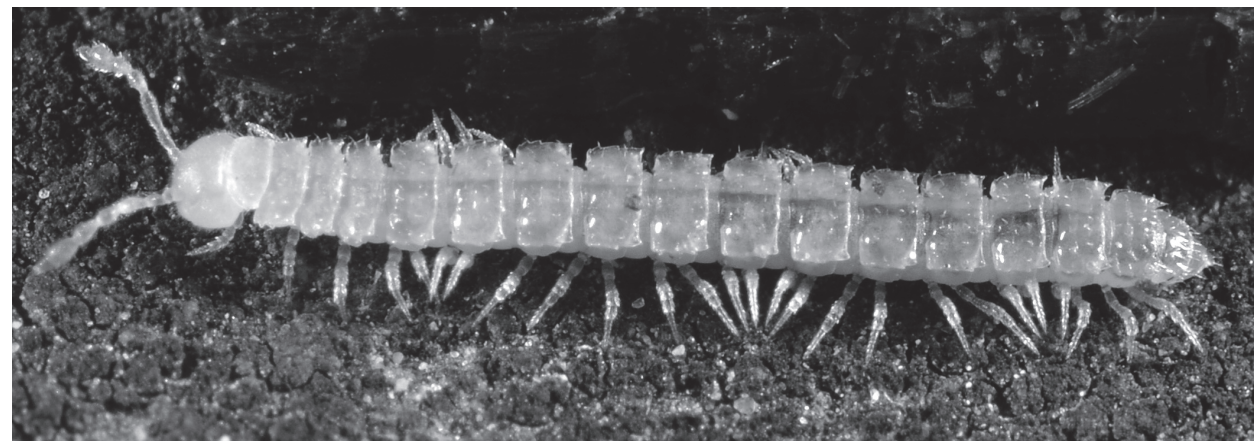

Fig. 3. Brachydesmus troglobius, male from Törökpince Cave (in situ photo by Z. Korsós)
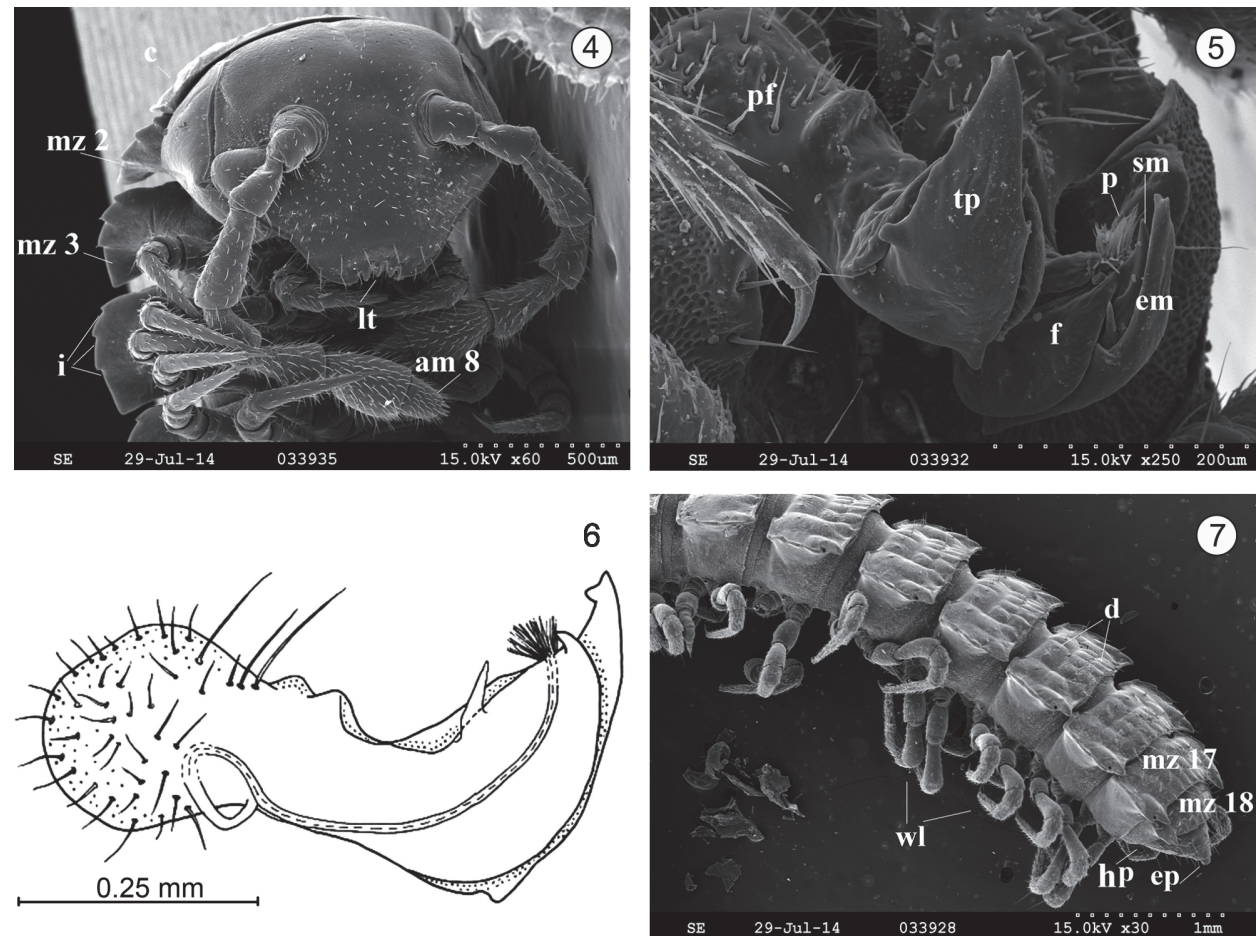

Figs 4-7. Brachydesmus troglobius, male from the Abaligeti Cave: $4=$ head, frontal view, scanning electron micrograph. am $8=$ antennomere VIII, $\mathrm{c}=$ collum, $\mathrm{i}=$ incisions, $\mathrm{lt}=$ labral teeth, $\mathrm{mz} 2$ = metazonite II, mz 3 = metazonite III; 5 = gonopods in situ, scanning electron micrograph. em $=$ exomerite, $\mathrm{f}=$ femorite, $\mathrm{p}=$ pulsilla, $\mathrm{pf}=$ prefemorite, $\mathrm{sm}=$ solenomerite, tp $=$ telopodite; 6 = right gonopod, mesal view; 7 = posterior body segments, dorsolateral view, scanning electron micrograph. $\mathrm{d}=$ dentate metazonite, $\mathrm{ep}=$ epiproct, $\mathrm{hp}=$ hypoproct, $\mathrm{mz} 17$ = metazonite XVII, mz 18 = metazonite XVIII, wl = walking legs 
Eastern collateral, lamp flora, 13/06/2012, leg. D. Angyal, det. Z. Korsós, 3 \&, 1 ठ̊; Törökpince Cave, $50 \mathrm{~m}$ from entrance, 11/06/2012, leg. D. Angyal, det. Z. Korsós, 1 , , 1 §̂.

Total body length 10-12 mm, eyeless, depigmented (from white to light brown). Adult males and females with 19 body rings ( $17+1+$ telson).

Head (Figs 2-4): Broader than collum, densely covered by minute setae. Three well developed labral teeth visible. Occipital sulcus visible. Antennae long, surpassing somite 3. Antennomere I length is $2 / 3$ of antennomere II. Antennomeres II, IV and V approximately equally long. Antennomere III longest among all. Antennomere VI slightly shorter than antennomere III. Antennomere VII length is $1 / 3$ of antennomere VI. One C-shaped sensitive seta on antennomere VII visible. All antennomeres densely covered with setae. Antennomeres IV-VII with 1-3 long sensitive setae. Subapically, antennomere VII with knob-supporting field of few sensitive microsetae. Apical antennomere with 4 large cones.

Collum (Figs 2, 4): Convex, anterior and posterior edge both semicircular without caudal incisions of lateral sides.

Body (Figs 2, 3, 7): Body segments gently broadening until segment VII, parallelsided from segment VIII to XV, and from segment XVI rapidly tapering toward body end. Metazonite II, III, IV, VI, VIII and XI with 3 incisions, while metazonite V, VII, IX, $\mathrm{X}, \mathrm{XII}-\mathrm{XVIII}$ with 4 incisions. Yellow colored ozopores laterally clearly visible on living specimens. Ozopores situated near caudal corner of paraterga on metazonite V, VII, IX, X, XII-XVIII. Posterior edges of metazonites dentate. Epiproct medium sized, subtriangular in dorsal view, slightly flattened dorsoventrally. Tip of epiproct rounded. Paraprocts semicircular, each with a knob-supporting seta. Hypoproct subtrapezoid. Male leg length medium, between 1.5-2.0 times as long as midbody height.

Gonopods (Figs 2, 5, 6): Telopodite a little longer than coxite. Prefemur shorter than femorite. Prefemoral setation normal, dense. Femorite slightly elongated and simple with a single exomerite. Distal loop of seminal groove relatively long. Accessory seminal chambers absent. Setose pulvillus large with armature. Solenomerite small. Exomerite small, delicately curved. Position of its base lateral, starts near recurved point of seminal groove. Exomerite slightly longer than femorite at best and separated from it by a sulcus.

\section{Molecular studies on B. troglobius and other polydesmids}

In the COI genetic distance matrix (Table 5) it was found that $B$. troglobius from the Abaligeti Cave differed only by $0.9 \%$ from B. troglobius collected in the Serbian Petnička Cave, and all substitutions proved to be synonymous. The two Hungarian Brachydesmus species (B. troglobius and B. superus) collected in caves from two different karstic areas, differed by $9.8 \%$. As it can be seen in the Bayesian tree (Fig. 8), among the studied taxa, the closest relative of $B$. troglobius is $B$. herzogowinensis, however, further analysis will be necessary, because the length of the single available $B$. herzogowinensis COI sequence was only $430 \mathrm{bp}$ long. Identification of a juvenile female specimen of Polydesmus denticulatus collected in the Solymári-ördöglyuk Cave was possible by comparison of its COI sequence with the $P$. denticulatus sequences available in GenBank. This P. denticulatus individual differed from the Hungarian 


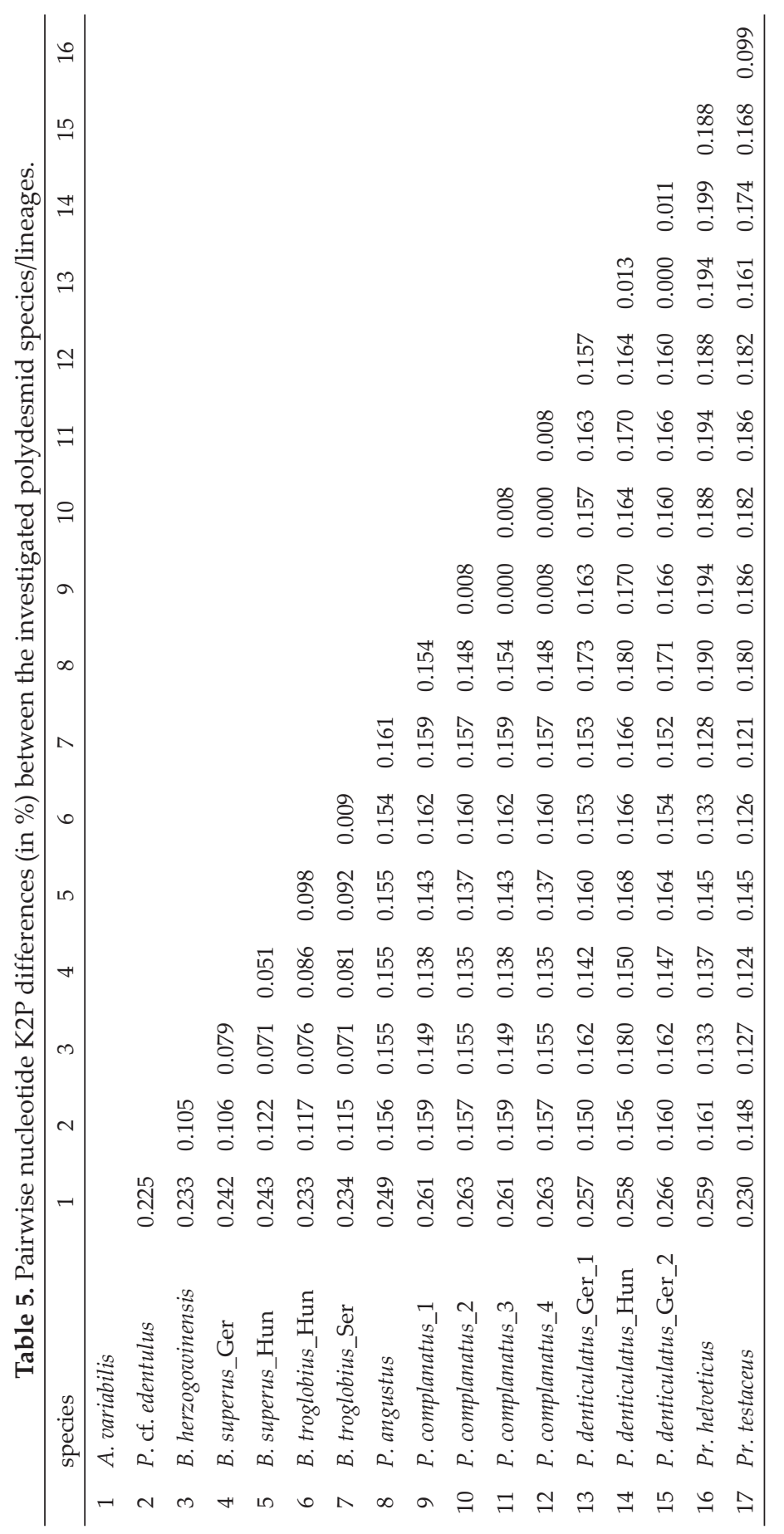


B. troglobius by $16.6 \%$. Distinct species within Brachydesmus had at least $7 \%$ and maximum $9 \%$ difference. Polydesmus cf. edentulus was found to be closer related to the Brachydesmus species (differed by 10.5-11.6\%) than to other Polydesmus species (differed by 15.5-15.8\%), which raises the question of the generic placement of this species. The maximum intrageneric distance was $17.5 \%$ within the genus Polydesmus. The average intergeneric distance within the genera Brachydesmus and Polydesmus was $15.5 \%$. Propolydesmus species differed in an average of $13.2 \%$ from Brachydesmus species and - not counting $P$. cf. edentulus -, $18.4 \%$ from Polydesmus species. The outgroup taxon A. variabilis differed by at least $22.5 \%$ from the other 16 taxa.

New distribution data for $\mathrm{B}$. troglobius and remarks on its ecology

Despite our repeated visits to 14 caves of the Western Mecsek Mts, Brachydesmus troglobius was found only in a single cave apart from its type locality. In the Abaligeti Cave they were distributed in the main passage, the Eastern collateral, and the Western 2 collateral (Fig. 9), feeding on the lamp flora and on decaying wood, or walking on the sediment, and rarely on speleothem forma-

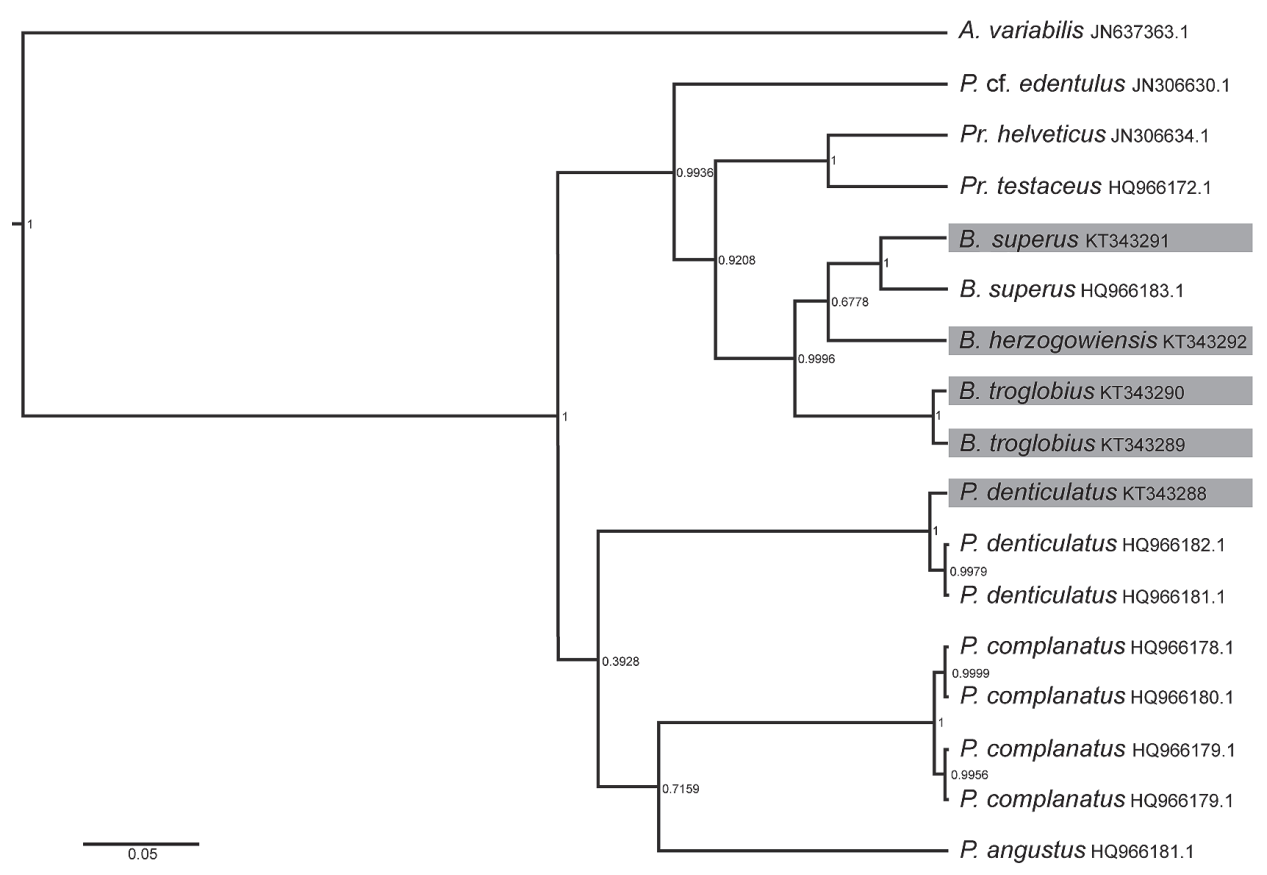

Fig. 8. Bayesian phylogenetic tree of 17 polydesmid taxa based on COI. Framed taxa represent own data 


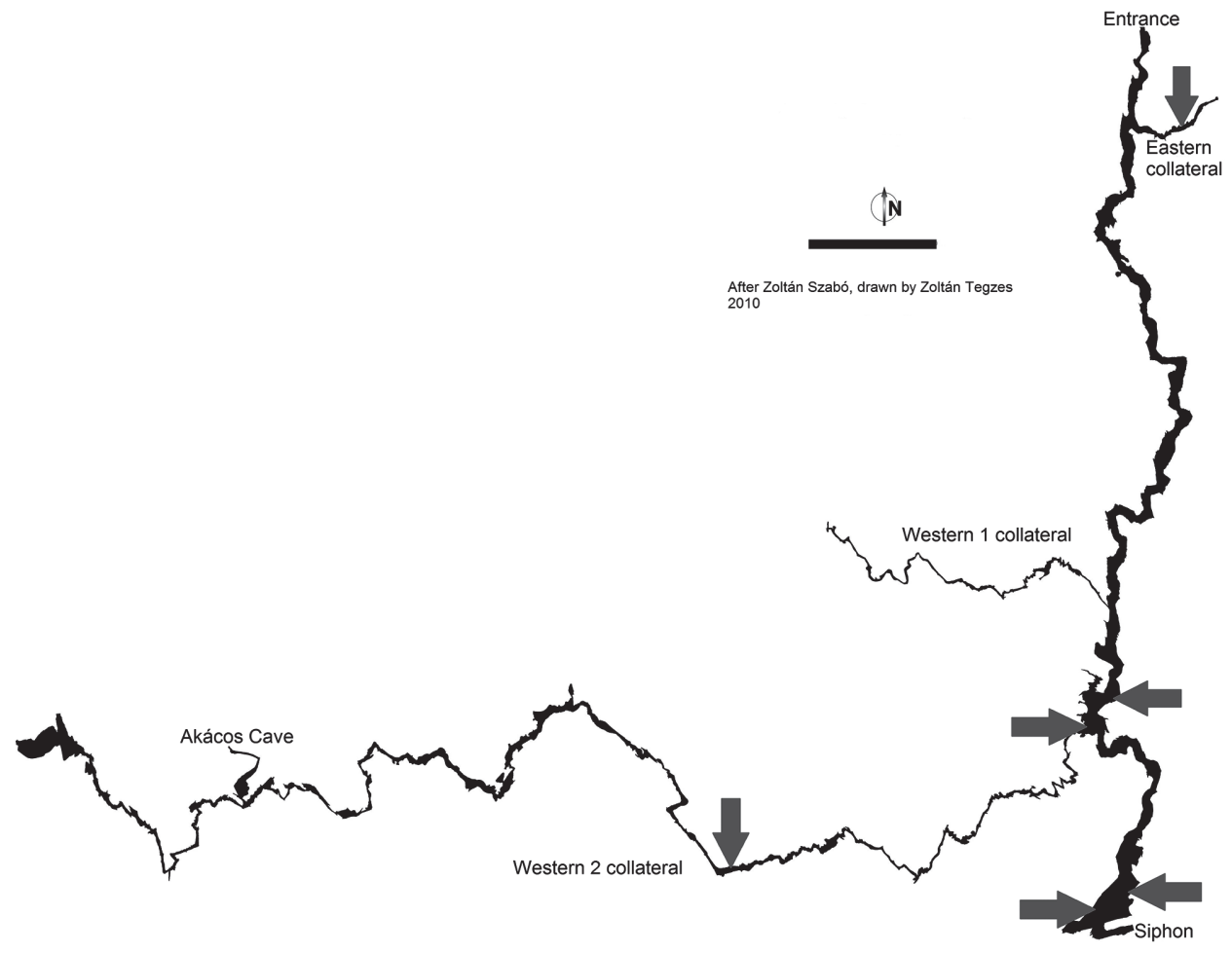

Fig. 9. Localities of Brachydesmus troglobius in the Abaligeti Cave
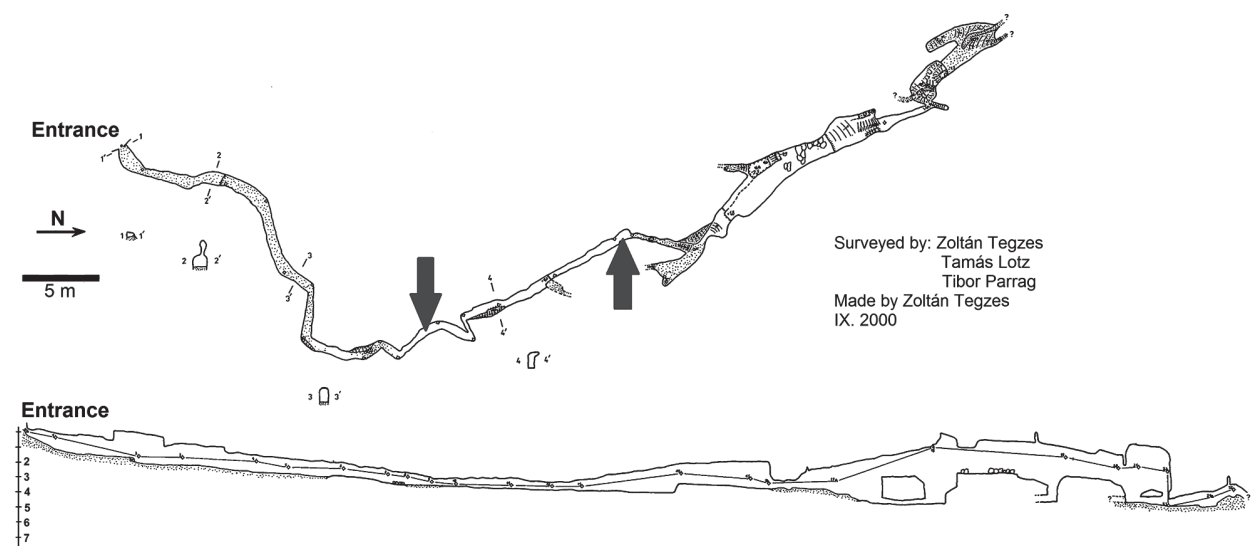

Fig. 10. Localities of Brachydesmus troglobius in the Törökpince Cave 
tions. Coexistence with the eutroglophile Trachysphaera schmidtii Heller, 1858 and the oniscoid isopod Haplophthalmus mengei (Zaddach, 1844) was observed on some occasions, especially on the vegetation developed on illuminated speleothems. B. troglobius was also found in the Törökpince Cave, where male and female specimens were collected at $30 \mathrm{~m}$ from the entrance and from the deeper zone of the cave (Fig. 10), usually close to decaying material.

\section{DISCUSSION}

Application of modern molecular phylogenetic methods and morphological studies on the polydesmid Brachydesmus troglobius enabled understanding its relationship with other taxa. COI sequences of individuals from the Serbian Petnička Cave and from the Abaligeti Cave showed only $0.9 \%$ K2P difference, which may suggest that the epigean ancestor, which had been distributed in the Carpathian Mts and the Dinaric Alps, started to colonize the underground habitats and to evolve in isolation during the recent geological past.

Identification of polydesmid diplopods in the absence of mature males is circumstantial in some cases. The example of Polydesmus denticulatus identified by comparison of COI sequences shows the value of complementing traditional morphology with molecular systematics. The results of the phylogenetic study of polydesmid species in this article may help in future delimitation of intrageneric and intergeneric boundaries of European Polydesmidae.

Due to the isolation of hypogean habitats of the Mecsek area, a high degree of endemism likely developed in cave millipedes. Verhoeff (1928) found very interesting the mixed zoogeographical character of the diplopod fauna of the Abaligeti Cave. He noted the relationship of Brachydesmus troglobius with the Croatian-Illyrian fauna, while he considered Hungarosoma bokori (Verhoeff, 1928), also found in the Abaligeti Cave (Konsós 2000), to be related to the Asian millipede fauna. The circum-Pannonian distribution of H. bokori corresponds with the hypothesis that Hungarosoma belongs to relict fauna of the microplates (mega-blocks) in the area of the present Hungary during the Tertiary period, which have recently slumped under sediments of the Pannonian Lowland (Моск et al. 2014, 2016). VerhoefF (1928) presumed the common lineages of Haasea hungarica (Verhoeff, 1928), another species from the Abaligeti Cave (Korsós 2000), and the Central European millipede species, thereby indicating a European instead of Asian affiliation.

Predation and competition for resources are less intensive in subterranean habitats than in epigean ones, due to the absence of higher trophic levels, to the low abundance of the species, and to the relatively constant environmental factors (Culver \& Pipan 2009). Brachydesmus troglobius seems to maintain a stable population in the Abaligeti Cave, using all types of vegetable organic 
material. Although the appearance of the lamp flora is both an aesthetic and conservational problem in public caves like the Abaligeti Cave, the vegetation confined to them seemed to be a regular source of energy not only for $B$. troglobius, but also for other detritivores (ANGYAL 2015). For this reason, the lamp flora should not be removed without considering the associated invertebrates. Live invertebrates could be recovered from manually removed vegetation by sifting or Berlese extraction on the spot, and could be transported to an unperturbed part of the cave, near to another potential nutrition source. Although B. troglobius is known from some other European countries, in Hungary the species possesses only one known locality apart from its type locality. Owing to their extremely narrow Hungarian distribution, the two local populations (one in the Abaligeti Cave and another in the Törökpince Cave) are rare and of potential conservation value.

Acknowledgement - Tímea Szederjesi (Plant Protection Institute, Hungarian Academy of Sciences and Department of Zoology, HNHM) is gratefully acknowledged for her help provided in phylogenetic analysis and in upload of barcode sequences. We are thankful to Dr. Krisztina Buczkó (Department of Botany, HNHM) for her help during the scanning electron microscopy. We are also grateful to Dr. Virág Krízsik and Mária Tuschek (Laboratory of Molecular Taxonomy, HNHM) for their help during the molecular studies. Gergely Balázs (Department of Systematic Zoology and Ecology, Eötvös Loránd University) is acknowledged for making Figure 1 and computer graphic editing some of the figures. We also thank to Tamás Németh (Department of Zoology, HNHM) for making the multilayer photos. Researchers of the Pro Natura Karst and Cave Research Society are acknowledged for their company during the sampling cave-trips. We are very grateful to the two anonymous reviewers who gave valuable suggestions to improve an earlier version of the manuscript.

\section{REFERENCES}

Angyal, D. \& Korsós, Z. (2013): Millipedes (Diplopoda) of twelve caves in Western Mecsek, Southwest Hungary. Opuscula Zoologica, Budapest 44(2): 99-106.

Angyal, D., Balázs, G., ZaKšeK, V., Krízsik, V. \& Fišer, C. (2015): Redescription of two subterranean amphipods Niphargus molnari Méhely, 1927 and Niphargus gebhardti Schellenberg, 1934 (Amphipoda, Niphargidae) and their phylogenetic position. ZooKeys 509: 53-85. https://doi.org/10.3897/zookeys.509.9820

Angyal, D. (2015): Integrative taxonomic revision of Niphargus spp. and other rare and endemic troglobiont macroinvertebrates from the caves of the Western Mecsek (South Hungary). PhD thesis, University of Pannonia, Georgikon Faculty, $136 \mathrm{pp}$.

Antić, D. Z., Ćurčić, B. P. M., Mitić, B. M., Tomić, V. T., Lucić, L. R., Dudić, B. D., Stojanović, D. Z. \& MaKarov, S. E. (2013): A new cave diplopod of the genus Brachydesmus Heller, 1858 from Southwest Serbia (Diplopoda: Polydesmida: Polydesmidae). Archives of Biological Science, Belgrade 65(2): 745-750. https://doi.org/10.2298/ ABS1302745A 
Вокок, Е. (1924): Beiträge zur rezenten der Abaligeter Grotte. Zoologischer Anzeiger 61: $111-121$.

Beueno-Villegas, J., Sierwald, P. \& Espinosa de los Monteros, A. (2008): Phylogeny of the millipede genus Sphaeriodesmus Peters, 1864 (Polydesmida: Sphaeriodesmidae) based on morphological characters. Organism Diversity \& Evolution 8(2): 99-120. https://doi.org/10.1016/j.ode.2007.03.001

Ceuca, T. (1992): Variability among some species of the genera Polydesmus and Brachydesmus (Polydesmida-Diplopoda) from Romania. Studia Univ. Babes-Bolyai, Biologia 37(1): 11-17.

Culver, D. C. \& Pipan, T. (2009): Biology of caves and other subterranean habitats. Oxford University Press, Oxford, $256 \mathrm{pp}$.

Ćurčić, B. P. M. \& Makarov, S. E. (1998): Postembryotic development in Brachydesmus troglobius Daday (Diplopoda, Polydesmidae) from Yugoslavia. Archives of Biological Science, Belgrade 50(1): 9-10.

DADAY, J. (1889): A magyarországi myriopodák magánrajza. [Monograph of the myriopods in Hungary.] Királyi Magyar Természettudományi Társulat, Budapest 126 pp. + I-III.

DAYrat, B. (2005): Towards integrative taxonomy. Biological Journal of the Linnean Society 85: 407-415. https://doi.org/10.1111/j.1095-8312.2005.00503.x

Djursvoll, P., Golovatch, S. I., Johanson, K. A. \& Meidell, B. (2000): Phylogenetic relationships within Polydesmus sensu lato (Diplopoda, Polydesmidae). Fragmenta Faunistica (Warszawa) 43: 37-59.

Drummond, A. \& Rambaut, A (2007): BEAST: Bayesian evolutionary analysis sampling trees. BMC Evolutionary Biology 7: 214. https://doi.org/10.1186/1471-2148-7-214

Enghoff, H. (ed.) (2013): Fauna Europaea. Myriapoda. Fauna Europaea, version 2.6.2, http://www.faunaeur.org [Downloaded on 22/07/2015]

Folmer, O., Black, M., Hoen, W., Lutz, R. \& Vrijenhoek, R. (1994): DNA primers for amplification of mitochondrial cytochrome c oxidase subunit I from diverse metazoan invertebrates. Molecular Marine Biology and Biotechnology 3: 294-299.

Gebhardt, A. (1934): Az Abaligeti barlang élővilága. Mathematikai és Temészettudományi Közlemények 37: 1-264.

Gebhardt, A. (1963): A Mecsek hegység barlangjainak biológiai vizsgálata. Janus Pannonius Múzeum Évkönyve 8: 5-32.

Gebhardt, A. (1966): Fauna of the Mecsek Mountains II. A Janus Pannonius Múzeum Évkönyve 11: 7-15.

Gebhardt, A. (1967): A Mecsek hegység állatvilágának térbeli elterjedése élőhelyek szerint. Janus Pannonius Múzeum Évkönyve 12: 7-14.

Havasi, I. (2003): A Mecsek-hegység fokozottan védett barlangjai. Pp. 388-394. In: SzéKely, K. (ed.): Magyarország fokozottan védett barlangjai. Mezőgazda Kiadó, Budapest.

Kimura, M. (1980): A simple method for estimating evolutionary rate of base substitutions through comparative studies of nucleotide sequences. Journal of Molecular Evolution 16: 111-120. https://doi.org/10.1007/BF01731581

Korsós, Z. (2000): Rare and endemic millipedes (Diplopoda) of the Abaliget Cave. Pp. 6166. In: Моск, A., Kovac, L. \& Fulin, M. (eds): Fauna Jaskýň. East Slovakian Museum, Košice

Korsós, Z., Read, H. J., Barber, A. D., Gregory, S. J., Hornung, E., Jones, R. E., Kime, R. D., Lewis, J. G. E. \& Selden, P. A. (2006): Report on a collecting trip of the British Myriapod Group to Hungary in 1994. Bulletin of the British Myriapod E Isopod Group 21: 40-55. 
Machordom, A., Araujo, R., Erpenbeck, D. \& Ramos, M. A. (2003): Phylogeography and conservation genetics of endangered European Margaritiferidae (Bivalvia: Unionoidea). Biological Journal of Linnean Society 78: 235-252. https://doi.org/10.1046/j.10958312.2003.00158.x

Makarov, S. E. (2004): The diplopods of Serbia, Montenegro and the Republic of Macedonia. Volume 9. Monographs/Institute of Zoology, Belgrad, 437 pp.

Makarov, S. E., Vujisić, L. V., Ćurčić, B. P. M., Ilić, B. S., Tesević, V. V., Vajs, V. E., Vucković, I. M., Mitić, B. M., Lucić, L. R. \& Dordević, I. Z. (2012): Chemical defense in the cave-dwelling millipede Brachydesmus troglobius Daday, 1889 (Diplopoda, Polydesmidae). International Journal of Speleology 41(1): 95-100. https://doi. org/10.5038/1827-806X.41.1.10

Marek, P. E. \& Bond, J. E. (2006): Phylogenetic systematics of the colorful, cyanide-producing millipedes of Appalachia (Polydesmida, Xystodesmidae, Apheloriini) using a total evidence Bayesian approach. Molecular Phylogenetics and Evolution 41: 704-729. https:// doi.org/10.1016/j.ympev.2006.05.043

MareK, P. E. \& Bond, J. E. (2007): A reassessment of apheloriine millipede phylogeny: additional taxa, Bayesian inference, and direct optimization (Polydesmida: Xystodesmidae). Zootaxa 1610: 27-39. https://doi.org/10.11646/\%25x

Mock, A., Tajovskŕ, K., Žurovcová, M., Angyal, D. \& Kocourek, P. (2014): Hungarosoma bokori Verhoeff, 1928 (Diplopoda, Chordeumatida), a tiny and enigmatic millipede: Redescription and new light to its systematics, ecology and biogeography. In: TuF, I. H. \& TAjovsкÝ, K. (eds): Book of Abstracts, 16th International Congress of Myriapodology, 20-25 July 2014, Olomouc, Czech Republic. p. 58.

Mock, A., Tajovskŕ, K., Žurovcová, M., Jarošová, A., Kocourek, P., Gruber, J., Angyal, D. \& SpeldA, J. (2016): Hungarosoma bokori Verhoeff, 1928 (Diplopoda: Chordeumatida): new insights into its taxonomy, systematics, molecular genetics, biogeography and ecology. Zootaxa 4178(2): 234-256. https://doi.org/10.11646/zootaxa.4178.2.4

Mršić, N. (1988): Polydesmida (Diplopoda) of Yugoslavia. I. Academia Scientiarum et Artium Slovenica, Classis IV, Historia Naturalis, Ljubljana 29: 69-112.

Mršić, N. (1994): The Diplopoda (Myriapoda) of Croatia. Razprave IV. Razreda SAZU, Ljubljana 35(12): 219-296.

Mršić, N. (1998): Polydesmida (Diplopoda) of Yugoslavia, I. Razprave IV. Razreda SAZU, Ljubljana 29(3): 69-112.

Simonsen, A. (1990): Phyogeny and biogeography of the millipede order Polydesmida, with special emphasis on the suborder Polydesmidae. Thesis, University of Bergen, Museu de Zoologia, Bergen,114 pp.

Schwarz, G. E. (1978): Estimating the dimension of a model. Annals of Statistics 6(2): 461464. https://doi.org/10.1214/aos/1176344136

Spelda, J., Reip, H. S., Oliveira-Biener, U. \& Melzer, R. R. (2011): Barcoding Fauna Bavarica: Myriapoda - a contribution to DNA sequence-based identifications of centipedes and millipedes (Chilopoda, Diplopoda). Zookeys 156: 123-139. https://doi. org/10.3897/zookeys.156.2176

Strasser, K. (1971): Catalogus faunae Jugoslaviae: Diplopoda. Volume 3. Academia Scientiarum et Artium Slovenica, 48 pp.

Szatyor, M. (2005): Telelő kolóniák monitoringja a Mecsek-hegységben és a Szársomlyón. [Monitoring of wintering colonies in the Mecsek Mountains and in the Szársomlyó]. Pp. 27-29. In: Molnár, V., Orbán, É. \& Molnár, Z. (eds): A II-IV. Magyar Denevérvédelmi Konferencia kiadványa [Proceedings of the II-IV. Conference on the Bat Conservation in Hungary]. Magyar Denevérkutatók Baráti Köre, Budapest. [in Hungarian] 
Rambaut, A. (2012): Figtree version 1.4.0. Available from: http://tree.bio.ed.ac.uk/software/ figtree/

Tamura, K., Stecher, G., Peterson, D., Filipski, A. \& Kumar, S. (2013): MEGA6: Molecular Evolutionary Genetics Analysis. Version 6.0. Molecular Biology and Evolution 30: 2725-2729. https://doi.org/10.1093/molbev/mst197

Thompson, J. D., Higgins, D. G. \& Gibson, T. J. (1994): CLUSTAL W: improving the sensitivity of progressive multiple sequence alignment through sequence weighting, position-specific gap penalties and weight matrix choice. Nucleic Acids Research 22: 4673-4680. https://doi.org/10.1093/nar/22.22.4673

Verhoeff, K. W. (1928): Zur Kenntnis der Diplopodenfauna Ungarns. 109. Diplopoden Aufsatz. Állattani Közlemények 25: 182-199.

Wojcieszek, J. M. \& Simmons, L. W. (2012): Evidence for stabilizing selection and slow divergent evolution of male genitalia in a millipede (Antichiropus variabilis). Evolution 66(4): 1138-1153. https://doi.org/10.1111/j.1558-5646.2011.01509.x

Received September 16, 2015, accepted August 10, 2016, published March 3, 2017 